\title{
A ADMINISTRAÇÃO LOCAL NO BRASIL IMPERIAL: notas preliminares sobre as municipalidades nos debates parlamentares.
}

\author{
Williams Andrade de Souza*
}

\begin{abstract}
RESUMO: Neste artigo abordaremos as municipalidades no Brasil imperial. A partir da historiografia e dos debates parlamentares em torno da Administração Local, cujo resultado, entre outros, foi a aprovação da Lei de $1^{\circ}$ de outubro de 1828 , buscaremos contribuir com o tema sobre as elites políticas ditas locais, entrevendo-as como componentes necessários e atrelados, por meios das leis e de suas práticas cotidianas, ao mosaico de institucionalização do Império Liberal brasileiro.
\end{abstract}

PALAVRAS-CHAVE: Câmara Municipal; Debates Parlamentares; Administração Local; Brasil Imperial.

\section{The Local Administration in Imperial Brazil: preliminary notes on municipalities in parliamentary debates.}

\begin{abstract}
In this article we will discuss the municipalities in imperial Brazil. Based on the historiography and the parliamentary discussions on Local Administration, which resulted in the approval of the law of October 1, 1828, among others, we aim to contribute to the debate on the local political elites, perceiving them as necessary components, linked by means of laws and their daily practices to the institutional mosaic of the Brazilian Liberal Empire.
\end{abstract}

KEYWORDS: Municipalities; Parliamentary Debates; Local Administration; Imperial Brazil.

\section{La administración local de Brasil Imperial: notas preliminares sobre los municipios en los debates parlamentarios.}

RESUMEN: En este artículo vamos a discutir sobre los municipios de Brasil imperial. Analizando la historiografía y los debates parlamentarios sobre el gobierno local, cuyo resultado fue, entre otros, la aprobación de la Ley del 1 de octubre de 1828, buscaremos contribuir en el debate sobre las élites políticas locales. Estos grupos fueron una parte integrante de la estructura institucional del Imperio liberal brasileño, vinculándose a ella por intermedio de las leyes y prácticas cotidianas.

PALABRAS-CLAVE: Municipio; Debates Parlamentarios; Administración Local; Brasil Imperial.

\footnotetext{
*Doutorando pelo programa de pós-graduação em história da Universidade do Vale do Rio dos Sinos, bolsista Capes/PROSUP. Professor pela Secretaria de Educação, Cultura e Esporte de Pernambuco, e Professor Pesquisador UAB/UFRPE. Email:willandsouza@hotmail.com.
} 


\section{A Administração local e as municipalidades nos debates parlamentares}

A temática sobre a construção e consolidação do Estado Nacional brasileiro oitocentista continua chamando atenção dos historiadores. Desde Francisco Adolfo de Varnhagen as linhas interpretativas multiplicaram-se, haja visto as múltiplas dimensões, abordagens e domínios que compõem os domínios da História. ${ }^{1} \mathrm{Na}$ faina historiográfica recente, certos debates sugerem o estudo do poder e das elites locais como interface para compreender as tramas dessa construção, pois há um entendimento de que grupos e instituições "menores" também exerceram papel significativo em tal processo. ${ }^{2}$ Não objetivamos entrar nessas questões aqui, mas lançar algumas notas preliminares sobre como as municipalidades no Brasil imperial foram inseridas na estrutura do governo sob uma perspectiva racional, e os respectivos desdobramentos e significados disso. A partir da historiografia sobre o tema e de fontes documentais, como os debates parlamentares em torno da administração local, cujo resultado, entre outros, foi a aprovação da Lei de $1^{\circ}$ de outubro de 1828, pretendemos discorrer sobre as municipalidades no período em tela. Buscaremos contribuir com o debate sobre as elites políticas ditas locais, entrevendo-as como componentes necessários e atrelados, por meios das leis e de suas práticas cotidianas, ao mosaico de institucionalização do Império Liberal brasileiro.

Na primeira Carta Constitucional, outorgada por D. Pedro I em 25 de março de 1824, competia à municipalidade o governo econômico ${ }^{3}$ dos espaços de sua atuação, confirmou-se a sua eletividade e determinou-se a posterior elaboração de uma lei regulamentar que determinaria "todas as suas particulares e úteis atribuições", 4 e representaria "um enorme avanço sobre a concepção colonial das funções das Câmaras que passaram a reger a vida municipal". 5 O novo Regimento, ${ }^{6}$ composto de noventa artigos, dispostos em cinco títulos, logo passou a vigorar e instituiu a "forma da eleição das Câmaras", as "funções municipais", as "posturas policiais", a "aplicação das rendas" e os "empregados". Rompendo com os padrões pouco estruturantes do período colonial, apresentava-se como um modelo de racionalização para a organização e o governo municipal. Tratava-se de uma normatização baixada do governo central para que os municípios com seus vereadores e juízes não se

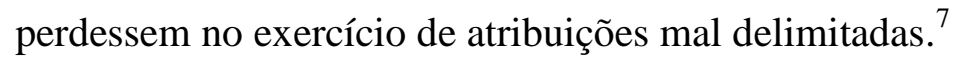

O arranjo decisivo para a elaboração dessa legislação se deu no noviço parlamento brasileiro, entre os anos de 1826 e 1828, quando este deu os primeiros passos para a consolidação de uma ordem constitucional iniciada em 1820 com o movimento Vintista, que impetrou a derrocada do absolutismo e a fundação de um novo ordenamento político para 
Portugal e o Brasil. $^{8}$ Após o interregno imposto pelo Imperador por meio da dissolução da Assembleia Constituinte de 1823, a Câmara dos Deputados, retomou os seus trabalhos regulares em maio de 1826. A ânsia por uma reestruturação jurídica da sociedade tomou lugar no respectivo Parlamento e a instituição passou a ocupar a partir de então um lugar decisivo no cenário político do Império ao longo dos oitocentos. ${ }^{9}$

Na esteira desse movimento, a Casa sugeriu a criação de uma Comissão de Leis Regulamentares, cuja responsabilidade era "apresentar o quanto antes os projetos das leis necessárias" para o Brasil, ${ }^{10}$ cujo intuito maior era fundar e ou remodelar o arcabouço institucional necessário ao Império. Inevitavelmente, esse processo iria modificar a configuração dos poderes, especialmente os locais. A partir de então, as instâncias legislativas, executivas e judiciárias de todo o Império passariam por importantes transformações, dentre elas, o escalonamento burocrático das autoridades e a busca pela eficácia das instituições.

No âmbito do Legislativo, a normatização e administração foram entendidas como dois pilares fundamentais e indissociáveis à organização do corpo social e político da nova nação. Nesse sentido, a ênfase de que caberia ao poder público buscar a eficácia na administração do Império significou, entre outras coisas, "a implementação de um novo arranjo entre os poderes nos âmbitos local e nacional". Dentro do "discurso de racionalização e institucionalização das relações entre o 'todo' e as 'partes'”, realizou-se a fundação dos governos provinciais, a criação dos cargos de juízes de paz e a reorganização das Câmaras municipais, ${ }^{11}$ dentre as quais, esta última nos interessa aqui.

As Câmaras municipais figuraram nos debates parlamentares de então como integrantes da administração; e esta, por sua vez, passava a ser parte importante do mosaico político-administrativo de sustentação do Império, urgindo por normalização. Assim, ao buscarem reformar a "administração", braço direito do Poder Público, ${ }^{12}$ os legisladores da nação, além da regulamentação do governo das Províncias, inevitavelmente precisaram fazer o mesmo com as municipalidades espalhadas em todo o território do Império, pincipalmente porque nelas se inseriam um séquito de cidadãos cuja participação política pesaria no jogo político-administrativo de então.

Dentre os que encararam a empreitada, tomou destaque o deputado geral por São Paulo, Diogo Antônio Feijó. Foi dele a iniciativa de elaborar e encaminhar em 1826 um projeto mais amplo "para regimento dos Presidentes das Províncias e Câmaras municipais". Tratava-se de uma proposta que abordava o ordenamento do governo das Províncias como um 
todo: prevendo o estabelecimento de um Regimento para os seus Presidentes, Tesouraria e Comandante de Armas, a criação e regulamentação dos Conselhos Gerais e do cargo de Juiz de Paz, e o novo funcionamento das Câmaras municipais. ${ }^{13}$

No projeto proposto por Feijó, as municipalidades integrariam a "Administração e Economia das Províncias", numa relação de dependência aos Conselhos Gerais, aos quais competiria rever, aprovar ou reprovar as posturas policiais elaboradas pela Câmara municipal e fiscalizar as despesas e receitas das mesmas, determinando o que conviesse a esse respeito. ${ }^{14}$ O texto, além de prever a ratificação de outras autoridades a nível local, também apontava para a criação de novas esferas de representação, o esvaziamento político das instituições municipais e sua subordinação à instância provincial. Por ser muito extensa, a proposta foi remetida à apreciação da Comissão de Leis Regulamentares da Casa. ${ }^{15}$ Em agosto do mesmo ano, foi impressa juntamente com outro projeto do deputado Nicolau Pereira de Campos Vergueiro, cujo conteúdo era destinado a regulamentar especificamente a "administração municipal", ${ }^{16}$ mas por ali parou. O debate sobre o tema só seria reiniciado na Câmara dos Deputados em 17 de maio de 1827, quando entrou na ordem do dia o projeto de Feijó, pois era o mais abrangente sobre o assunto.

Por se tratar de uma "reforma geral na administração", Bernardo Pereira de Vasconcelos propôs que os colegas tratassem inicialmente "dos juízes de paz e das câmaras, porque estas autoridades [eram] as que por ora [eram] as mais essenciais." Luiz Francisco de Paula Cavalcanti endossou e propôs a divisão do projeto em partes para se "tratar cada uma cousa de per si, porque cada uma administração se faz por uma forma". Tratava-se de "regimentos das diferentes autoridades", devendo se discutir "cada um em separado e por sua vez". Concordando com Paula Cavalcanti, Vasconcelos disse que se assim fosse se poderia "apressar o estabelecimento das autoridades constitucionais, sem ficar dependente das outras partes". ${ }^{17}$ Por questões de ordem regimental, o projeto não poderia ser desmembrado, mas não haveria problema debatê-lo em doses homeopáticas, dando-se atenção inicial à matéria de maior necessidade: o Regimento das Câmaras; e, em segundo lugar, dos juízes de paz, ficando os demais tópicos adiados para sessões futuras, segundo José Clemente Pereira. ${ }^{18}$

Apesar de uma ou outra fala secundarizar a administração municipal e querer reduzi-la a capacho do governo provincial, foi vitorioso o discurso da especificidade de cada instituição e a determinação dos seus respectivos espaços de poder. As "diferentes autoridades" deveriam ser definidas e debatidas em separado. Ademais, elas eram "autoridades constitucionais", ou seja, faziam parte de um organismo maior. Estava em jogo a "reforma 
geral na administração", portanto, mais que regulamentar uma instituição secundária e de pequena monta, entrava na ordem do dia por em efeito a "Polícia Administrativa" de que o Império precisava, conforme veremos adiante. Portanto, não se tratava de uma simples tentativa de apagamento das municipalidades, pelo contrário: os legisladores buscariam evidenciar e fortalecer o papel administrativo delas nos vários recantos do Império, ordenando as suas instituições, definindo a especificidade de atuação de cada uma delas a partir da noção de divisão dos poderes.

Endossa o nosso argumento o fato de que, no Senado, discussões de mesmo teor sobre a fundação e/ou normatização das instituições locais/regionais, tramitavam pari passu às da Câmara dos Deputados. No dia 18 de maio de 1827, o mesmo Clemente Pereira deu notícias de que a "Casa Vitalícia" estava tratando especificamente de um Projeto de Leis sobre as Municipalidades. ${ }^{19}$ Por essa razão, os deputados cuidaram em discutir apenas a parte do projeto de Feijó que dizia respeito ao Regimento dos juízes de paz, e aguardaram o das Câmaras municipais, de que falara Clemente ${ }^{20}$. Somente em 1828 o tema retornaria à Casa baixa. Por ora, vamos nos deter nos debates travados pelos senadores sobre o assunto, buscando entrever os indícios das assertivas que lançamos acima.

\section{O governo local nos debates do Senado}

Como bem observou Vantuil Pereira, coube ao Senado discutir e aprovar o projeto que reconfigurou as municipalidades no Império. Posteriormente, a Casa baixa ratificou a votação dos senadores, indicando apenas algumas mudanças. Segundo ele, diferente do que disse Iara Lis Carvalho Souza, ${ }^{21}$ “o processo de esvaziamento do poder das Câmaras Municipais partiu da instituição que serviu de anteparo para o Imperador [...], não dos seus opositores". ${ }^{22}$ Contudo, como já sinalizamos, mais que esvaziar os poderes dessa ou daquela instituição ou autoridade, estava em jogo o ordenamento da nova nação, e isso implicava na reforma e/ou criação do arcabouço burocrático-institucional que passaria a compor a base de sustentação do sistema de governo então adotado. Nesse sentido, tanto os senadores quanto os deputados orquestraram um arranjo que conformasse os interesses comuns em benefício da institucionalização do Estado em formação. Nesse contexto, as Câmaras municipais teriam um novo papel a cumprir, devendo caminhar atreladas aos governos provinciais, e em consonância com o matiz Imperial.

No Senado, a Lei sobre as Municipalidades rendeu igualmente longo debate. ${ }^{23}$ Em 01 de junho de 1827 deu-se a primeira e a segunda discussão sobre a mesma. O primeiro artigo, 
que versava sobre o número dos vereadores que deveriam ter as Câmaras, de pronto foi tema de controvérsias que nos interessam aqui. $\mathrm{O}$ texto original previa sete membros para as cidades e cinco para as vilas. As opiniões entre os debatedores divergiram nesse ponto: um sugeria que o número fosse de cinco para ambos os lugares, alegando que havia um risco de que fossem eleitos homens maus para o cargo, pela "falta de pessoas hábeis para aqueles lugares"; outro, que a quantidade deveria superar o previsto na proposta inicial, e devendo as Câmaras citadinas ter um número maior de membros que as das vilas, pois, nas cidades, havia muito mais negócios a se tratar. ${ }^{24} \mathrm{O}$ consenso foi pela manutenção do texto original, mas, na lei final sancionada em 1828, ficou determinado que as Câmaras das cidades teriam nove vereadores, e, as das vilas, sete, conforme retomaremos adiante.

O interessante é que, entre emendas e escusas sobre o assunto, dois pontos nos chamaram a atenção: os comentários sobre os homens da municipalidade e sobre a função dessas instituições. Sobre o primeiro, o pouco que se falou partiu do senador Soledade, ao dizer que até aquele momento a falta de pessoas hábeis para aquela função se dava porque "os lugares de vereadores limitavam-se somente a certas classes". ${ }^{25}$ Anteriormente o Marquês de Caravelas já havia dito que o aumento do número de vereadores para a Câmara também poderia facilitar a escolha de homens bons. ${ }^{26}$ Portanto, há nessas falas uma alusão à ampliação e renovação dos quadros camarários, o que poderia favorecer o bom governo local. Também estava intrínseca a ampliação da participação política dos cidadãos nos processos eleitorais. Orquestrar a integração dessas categorias em tais espaços de poder poderia favorecer o Estado, pois este precisa de pessoas aptas para compor os seus quadros.

Sobre o segundo ponto, destaca-se a assertiva do mesmo Marquês quando disse que a lei em questão impunha às Câmaras "a Polícia Administrativa", que, a seu ver, até então elas não tinham. Ou seja, para ele, as municipalidades precisavam de "responsabilidade, e para melhor preencherem os seus deveres" era preciso que "fosse também maior o número dos seus membros", sendo "princípio certo que o trabalho repartido é melhor dirigido, e maior vigilância se pode empregar na sua execução". ${ }^{27} \mathrm{Na}$ fala há um entendimento de que era necessário definir bem o papel da instituição. Percebe-se também que os argumentos se complementam: era preciso aumentar a quantidade de homens na Câmara a fim de que os trabalhos da mesma fossem executados com eficiência.

No contrapé dessas falas, o senador Borges argumentou: se houvesse o aumento do número dos vereadores, se tivesse "maior abundância de gente elegível e se este se quisesse prestar, porém, que incentivo [propunha] a lei para isto? Que honras ou ordenados arbitra[va] 
para quererem suportar esses ônus?”. Acrescentou ainda que em alguns lugares era difícil encontrar homens capazes para tais funções, ou por eles não existirem ou por se escusarem ao cargo que só lhes trazia "despesas e malquerenças, deixando-os, depois do tempo de serviço, no mesmo estado em que existiam antes". Sendo que essa dificuldade só aumentaria, pois, dali em diante, sairiam "da parte melhor da Nação tantas pessoas para os Conselhos de Governo, Conselhos de Província, Deputados e Senadores". ${ }^{28}$

Ainda sobre os cargos eletivos nas Câmaras Municipais, a discussão seguinte referiuse às eleições dos vereadores, sua forma, lugar e data. ${ }^{29}$ Para os legisladores as funções da vereança eram responsabilidades que requeriam de seus interessados, pelo menos, um mínimo de saberes sobre o lugar em que iriam atuar. Assim, o candidato à vaga precisava ter no mínimo dois anos de residência no domicílio, para "ter conhecimento do país e discorrer sobre os objetos que lhe dizem respeito e tem de tratar em razão daquele cargo", 30 além dos pré-requisitos dispostos na Constituição (sexo, maioridade, renda, etc. ${ }^{31}$ ).

Em ambos os debates, o que aproximava aqueles homens da lei era o fato de que as municipalidades careciam de estatutos mais claros e objetivos que lhes impingissem maior eficiência de governo, inclusive para poderem acalentar melhor os homens partícipes delas e cumprirem melhor as suas prerrogativas em cada localidade. Acrescente-se também que os debatedores acima perceberam que o alargamento da participação dos cidadãos nas esferas político-administrativas poderia trazer para a cena outros tantos indivíduos que em tempos passados não o poderiam. O exercício da cidadania mais uma vez vinha à tona no debate, e os senadores cuidaram em determinar quais os critérios para acessar tais espaços de poder e como isso devia ser feito. ${ }^{32}$ Neste mesmo raciocínio, buscaram adequar tais instituições e seus homens às demandas emergentes do Império, marcar as suas atribuições, limitar qualquer pretensão de novos grupos que ascendessem àquela instância.

Ainda sobre o cargo, o artigo 12 da proposta determinava que se o cidadão deixasse de votar e não apresentasse justificativa legítima, recairia sobre ele uma pena pecuniária de dez mil réis e o impedimento de participar em tais eleições pelo prazo de dois anos. Diante das controvérsias sobre o artigo, foi proposta a supressão do mesmo. Partiu do Visconde de Cairu a emenda nesse sentido. O curioso é que político fizera parte da Comissão que elaborou o respectivo projeto de lei, mas discrepava de algumas posições propostas nele. A seu ver, a parte penal do mesmo era "menos liberal que a antiga Lei Pátria" (a Constituição). Também salientou que a proposta diminuía a jurisdição das Câmaras municipais, as carregava de ônus, responsabilidades, encargos "e nada mais se lhe atribuiu de honorífico e útil". ${ }^{33} \mathrm{O}$ artigo 
passou, e só a parte do impedimento de votar é que foi suprimida. Se "a nova legislação devia ser somente diretiva, e não compulsória", ${ }^{34}$ o que prevaleceu foi consenso em torno da ordem, das leis e da causa pública levada em consideração. Assim, os ajustes se seguiriam, e as questões de valor "honorífico" cederam lugar à reconfiguração do papel das municipalidades a partir de um princípio racional em prol da eficácia administrativa.

Não por acaso, um dos pontos decisivos nos debates dos senadores foi a discussão sobre a definição das Câmaras como corporações meramente administrativas, eliminando-se a sua jurisdição contenciosa. Para alguns senadores era natural que o tema fosse aprovado na íntegra, pois as Câmaras já "não tinham jurisdição contenciosa, e, depois da separação dos diferentes poderes, menos teriam". ${ }^{35}$ Segundo o Visconde de Alcântara, a jurisdição existia e dizia respeito aos casos previstos nas Ordenações Filipinas (ainda em uso): nos de injúrias verbais e pequenos furtos; nos apossamentos de caminhos e servidões públicas por particulares; e, nas apelações dos negócios de almotaçaria que não fugissem de sua alçada. Assim, segundo ele, em qualquer outro caso que se intrometessem, cometeriam abuso de poder. Por isso, redarguiu: "para que ordenou a Constituição que se fizesse esta lei?". Ele mesmo respondeu: "foi para vedar essa mesma jurisdição contenciosa que exerciam as Câmaras, e pôr as suas atribuições em harmonia com o sistema constitucional". Obviamente, o dever de julgar dizia respeito aos juízes e não às Câmaras, logo, o artigo deveria passar na íntegra. $^{36}$

O Marquês de Inhambupe, que a princípio estava inclinado a sustentar o artigo por considerá-lo coerente com o sistema, opinou que se tratava de uma matéria para ser deliberada quando se discutisse sobre as atribuições daquele "ramo da administração pública". Não estava convencido se tal ramo deveria continuar da mesma maneira, ou que se lhe fosse negado toda e qualquer jurisdição contenciosa. ${ }^{37}$ Já Carneiro Campos, ponderando sobre o assunto, sugeriu que deveria haver flexibilidade na lei a fim de que as instituições pudessem fazer executar as suas providências e mandados. Ou seja, em sua opinião, não era intenção dos legisladores que as Casas locais deixassem "de ter meios para fazer cumprir os seus mandados". Não se tratava, portanto, "de colocar as Câmaras em menor dignidade do que elas tinham", pelo contrário, o sistema de então lhes seria "mais favorável", 38 pois que legitimava a especificidade de cada poder, dando condições para a boa atuação das respectivas autoridades, segundo o entendimento dos legisladores. Os dois senadores viam a questão como melindrosa, por isso sustentaram que era preciso adiá-la para se pensar melhor sobre o tema. 
Contundente, o Marquês de Caravelas foi contrário ao adiamento. Temia que, nos passos seguintes, a Casa desse certa atribuição judiciária às Câmaras. ${ }^{39}$ Confirmando os seus temores, João Evangelista sugeria: para a utilidade pública, a Constituição admitia em alguns casos o poder misto, isto é, certa autoridade para governar, legislar e julgar, "para usar da parte administrativa com proveito". Sendo também ratificado pelo Marquês de Inhambupe, que até questionou: "não pode, pois, esta lei dar às Câmaras alguma jurisdição contenciosa? Em que se vai aqui ofender a Constituição?". 40 Ao retrucar, o senador Caravelas esclareceu que "o Poder não é jurisdição". De sua fala depreende-se que as Câmaras poderiam ter poder misto, isto é, múltiplas funções, mas apenas administrativas e limitadas ao governo econômico e municipal das cidades e vilas. Julgar seria função de outra autoridade, pois "esse poder misto, por força que o há de ter todo aquele que for encarregado de qualquer autoridade, [...] não tira que a parte lesada haja de recorrer [a outro] poder legítimo". ${ }^{41}$ A fala do Marquês foi endossada em seguida pelo Visconde de Alcântara, ao salientar que "a Constituição marcou positivamente qual deveria ser a marcha judicial", designando "as autoridades a quem compete o julgar" ${ }^{42}$ Tais poderes não podiam ser estendidos às Câmaras. Ficava mais uma vez evidente que a intenção de muitos legisladores era que a instituição camarária caminhasse apenas dentro do viés administrativo.

Naqueles discursos os termos ganhavam sentido ao sabor dos argumentos. Para alguns senadores, permitir certa contenção jurisdicional para a instituição municipal era uma forma de proteger o princípio da administração, a saber, o seu bom funcionamento. Para outros, a proteção da lei já seria o suficiente e competiria ao poder judiciário o ato de julgar e fazer valer as suas prerrogativas. É possível notar, portanto, que a confusão entre os senadores girou em torno do termo "jurisdição contenciosa", visto, no geral, como atribuições judiciárias, e não como autoridade de contestação. ${ }^{43} \mathrm{Ou}$ seja, segundo o consenso vitorioso, se a expressão fosse mantida convencionaria um poder contencioso intrínseco às autoridades municipais, portanto, poder de polícia judiciária. Com isso, quando elas tomassem parte em querelas advindas de sua própria ação administrativa também teriam autoridade de juízes para arbitrar sobre a questão. Isso seria inconcebível num sistema liberal pautado na divisão dos poderes instituídos, como é possível entrever nos respectivos discursos.

Destarte, o artigo foi aprovado como na redação original. No final das contas, cumpria às Câmaras o governo econômico, não o judicial. Como as atribuições da instituição ser coerentes com a natureza da governança, e, no conjunto, estar em acordo com a Constituição, ela não teria jurisdição contenciosa, mas somente autoridade administrativa. No entanto, 
mesmo que a municipalidade não exercesse função de justiça, poderia recorrer ao arbítrio da lei, quando, nos limites de suas atribuições e no exercício dos seus deveres, fosse interpelada por oposição de pessoa ou outra autoridade qualquer. Nesse caso, só o poder judicial poderia fazer valer os seus respectivos direitos. ${ }^{44}$ Haveria, assim, harmonia com a prescrição Constitucional. E esse era o cerne da questão entre os legisladores: efetivar a ordem estabelecida a partir da Carta Magna.

Na sequência dos trabalhos da Casa, entrou em discussão que as Câmaras teriam a seu cargo tudo quanto dissesse respeito à polícia e economia das povoações e seus termos, pelo que tomariam deliberações e proveriam por meio das posturas. ${ }^{45}$ Dentre as várias questões que foram dispostas, a do parágrafo 8 trouxe de volta o tema da jurisdição para o debate e é interessante para se pensar um pouco sobre a importância das leis municipais para o governo cotidiano da cidade. No caso do dito parágrafo acima, por meio dele as municipalidades deveriam proteger os criadores e todas as pessoas que trouxessem gado para vender nas cidades ou vilas, castigando com multas e prisões os agentes do registro, marchantes ou atravessadores de gado que os oprimissem. ${ }^{46}$ Foi essa prerrogativa de interpor punição que causou novamente desentendimento entre os debatedores. Para o Visconde de Alcântara, se as câmaras não tinham jurisdição contenciosa, não podiam impor penas. ${ }^{47}$ Mas o senador Oliveira replicou que se devia dar essa autoridade para as Câmaras, como meio conveniente para fazer respeitar e obedecer as suas ordens. ${ }^{48}$ Nesta mesma linha, asseverou Carneiro de Campos, não se devia "tirar às Câmaras todo o poder coercitivo e correcional" ${ }^{49}$ No fim, a proposta foi aprovada, haja vista o entendimento de que a municipalidade necessitava de ferramentas para fazer valer as suas ações dentro do especificado em suas atribuições. Não seria possível elaborar uma postura sem a sanção correspondente, isso limitaria o efeito esperado. ${ }^{50}$

Os demais parágrafos desse artigo, mesmo tratando de atribuições que ora eram vistas como "coisas meramente econômicas" - como a fiscalização dos abatedouros públicos; ora como "judiciosas" - como a arrematação dos aluguéis das casas de açougue sem restrição dos números dos talhos particulares, entre outras tantas, tiveram dirimidas as dúvidas, feitas as supressões ou acréscimos, e acabaram sendo aprovados por se tratarem de parte essencial da polícia administrativa que cabia às municipalidades. Assim findou-se a discussão sobre o título que na lei sancionada em 1828 ficou conhecido como Posturas Policiais. A ratificação dos mecanismos considerados necessários para o bom governo da cidade foi um traço indelével que marcou os debates e a aprovação do respectivo título. 
Outro ponto interessante para nós se deu quando da discussão sobre a competência das Câmaras para supervisionar as Escolas de Primeiras Letras, educação e destinos dos órfãos, criação e conservação das casas de Caridade, concorrendo para a prosperidade e aumento deles quando tais estabelecimentos estivessem sob a delegação de outra autoridade. ${ }^{51}$ Aparentemente, o artigo passaria sem delongas. Mas não foi bem assim. Alguns senadores colocaram que as Câmaras nada tinham a ver com as escolas, que não as podiam inspecionar, que isso pertencia a outra autoridade. Mas para outros legisladores, como o Marquês de Caravelas, por exemplo, as Câmaras figuravam como uma das principais autoridades mais bem inteiradas das coisas locais, pois eram "compostas de cidadãos domiciliados no distrito, chefes de família provavelmente com filhos, e, por consequência, interessados na conservação e boa ordem desses estabelecimentos" (das escolas). No mais, "o artigo 72 da Constituição dava às Câmaras o direito de intervirem em todos os negócios do peculiar interesse das províncias", competindo-lhe inclusive "dirigir representações aos Conselhos Gerais das Províncias, na forma do Artigo 52" da mesma Lei, isto é, "intervir nos negócios de público interesse". 52

No entanto, a principal questão era que no futuro um possível conflito de jurisdição se podia estabelecer entre as Câmaras e as autoridades que porventura estivessem encarregadas daquela função. Havia um entendimento dúbio sobre o termo "concorrerão". Segundo o senador Borges, no sentido dado pelos redatores da lei, as Câmaras trabalhariam (concorreriam) conjuntamente com as autoridades incumbidas daqueles estabelecimentos. Isso poderia causar disputas entre as respectivas instâncias. Sugeriu, assim, que se mudasse a palavra por outra. Após mais algumas falas, ficou estabelecido na lei que as Câmaras auxiliariam a tais autoridades, sempre quando estivesse em sua parte. ${ }^{53} \mathrm{Em}$ linhas gerais, os legisladores reconheciam a potencialidade das municipalidades para gerir as coisas pertinentes às localidades, mas também entendiam que elas interagiriam com outras tantas instâncias locais. Portanto, entendiam que precisavam dar forma às diversas instâncias que compunham o aparelho de governo, e circunscrever cada uma delas em seus respectivos espaços de poder. Isso minimizaria os embates e fortaleceria a prática administrativa cotidiana, segundo o entendimento daqueles homens.

Após a discussão sobre os oficiais que seriam necessários para os serviços da municipalidade, ${ }^{54}$ indicando-se quem e como se executaria as tarefas pertinentes ao cotidiano administrativo das vilas e cidades, e que salário perceberiam os que se prestassem a tais serviços, ${ }^{55}$ seguiram-se as últimas discussões sobre as municipalidades. Nas ocasiões, se pôs 
em revista todo o projeto até então debatido, mas com poucas alterações. ${ }^{56}$ Ratificou-se "que as Câmaras não tinham senão jurisdição administrativa", e que havendo questões contenciosas, deveriam ir ao Juiz para as decidirem. ${ }^{57}$ Confirmou-se o adiamento da discussão sobre os juízes almotacés, deixando-se para tratar disso quando se discutisse a Lei dos Juízes de Paz, pois para estes seriam transferidas parte das atribuições de almotaçaria. ${ }^{58}$ Após mais alguns artigos, deu-se, por fim, terminada a discussão, ${ }^{59}$ e, aprovado o projeto, remeteu-se para a Câmara dos Deputados. ${ }^{60}$

\section{O governo local nos debates dos Deputados}

A Casa baixa recebeu o projeto de lei e o remeteu para uma Comissão especial dar um parecer e propor uma emenda geral se necessário. ${ }^{61}$ Após a revisão e a proposta de algumas alterações, o debate enfim se iniciou. A primeira questão da ordem do dia foi sobre a quantidade necessária de vereadores para as cidades e vilas. Tal qual queriam alguns da casa senatorial, esta foi alterada para nove e sete ocupantes, respectivamente, assim como a duração de cada mandado - modificada de dois para quatro anos. Segundo os deputados, isso era para se permitir a participação de um número maior de indivíduos que tivessem direito de intervir nos negócios de sua província, e para se atenderem as necessidades da administração local, harmonia no sistema e ordem nos negócios. ${ }^{62}$

Na parte dos requisitos para ser eleito vereador, houve também ponderações a respeito da obrigatoriedade do indivíduo de ter pelo menos dois anos de domicílio e ser votante nas assembleias paroquiais. O Deputado Castro e Silva demonstrou preocupação em se admitir "elementos tão heterogêneos" para um cargo com "funções de alta transcendência" e "vivo interesse pelos negócios do país". Para ele, devia haver mais restrições para tal acesso. Ao passo que, para Xavier de Carvalho, era "necessário dar latitude à elegibilidade", não impedindo a possibilidade do cidadão "formar parte de uma boa representação nacional". Neste mesmo raciocínio, para o deputado Ferreira de Mello, bastava que os habitantes de um munícipio reconhecessem "em um cidadão capacidade, luzes e patriotismo para bem exercer o emprego de vereador" ${ }^{63}$. No mesmo sentido da Casa Vitalícia, entendia-se que nas mudanças legislativas em curso o grau de participação dos cidadãos no processo político havia sido alterado, podendo levar à cena figuras outrora "desabilitadas". Isso também foi levado em consideração pelos parlamentares, impingindo neles a obrigação de regular esse processo sem ferir as "luzes do século" que empanavam o Estado liberal, segundo pensamento vigente. 
Assim, buscaram também ratificar a regulação da participação política dos cidadãos na eleição e na gerência dos negócios públicos, uma vez que essa havia sido "alargada" a partir da Constituição de $1824 .{ }^{64}$ Contudo, os deputados não agiram com menoscabo da função, mesmo discordando de um ou de outro ponto, assentiram que era preciso cuidado para que a vereança fosse ocupada por pessoas de boas intenções e condições para desempenhar adequadamente o cargo. Ou seja, comungavam que a função requeria pessoas capazes, entendidas e com competência para gerir os ramos da administração local.

A discussão ficou novamente renhida quando se tratou da matéria sobre a polícia e economia das povoações e seus termos. O deputado Lino Coutinho asseverou que as Câmaras não deveriam ter "a seu cargo tudo o que di[sesse] respeito à palavra polícia", pois esta era dividida em várias partes. Acrescentando: “como é que as câmaras pode[ria]m entender, por exemplo, da polícia médica?”. Mas para Araújo Bastos esse não era o problema, a questão era que a matéria deveria ser bem discutida "para esclarecer as Câmaras Municipais qual e[ra] a polícia que compe[tiria] a seus municípios". Nessa mesma linha, o deputado Augusto Xavier disse que o que se trazia eram atribuições próprias das Câmaras e economia do município. ${ }^{65}$ Por fim, os parlamentares que concordaram com o tema e explicitaram tais obrigações, apontaram que as mesmas estavam circunscritas ao âmbito municipal. Também não ficou evidente que se queria depreciar aquelas funções, pelo contrário, a intenção era de que os vereadores ficassem bem inteirados delas a fim de as exercerem com cautela e probidade.

O último embate entre os parlamentares surgiu quando se tratou do artigo que obrigava as municipalidades a arcarem com as festas em suas localidades. Dentre as falas contrárias ao proposto, salientamos a do deputado Feijó: "Como se há de dizer que as atribuições da Câmara [são] de fazer festas? Não sei como possa entrar na ideia do governo municipal [...]"; já o deputado Costa Aguiar disse: "que tem estas festas com as diversas atribuições [...] administrativas e até policiais que concedemos à Câmara? Por que motivos devemos incumbir nós as Câmaras de funções tão diversas da boa administração, comodidade e bem estar do município?" ${ }^{66}$ Ficava claro que as matérias pertinentes ao cotidiano dos vereadores deveriam estar associadas às questões administrativas que dissessem respeito ao governo dos municípios. Por fim, os deputados concluíram os debates sobre a lei ${ }^{67}$. Em seguida, o Senado aprovou interinamente as emendas e adições feitas pela Câmara dos Deputados ao projeto, dirigindo-o para a sanção do Imperador. ${ }^{68}$ 


\section{Considerações finais: A administração e a elite local e além}

Do ponto de vista dos legisladores, eles deram para as Câmaras "algumas atribuições bem importantes", ${ }^{69}$ sendo muitas delas de cunho específico. Em certa medida, eles buscaram tratar as matérias como casuísticas, ou seja, como temas que precisavam ser discutidos em miúdo. Apesar da especificidade de cada tarefa, a administração local por vezes foi assemelhada à provincial. Salvo as desproporções e diferenciação de funções que eram exclusivas do governo provincial, o consenso entre os parlamentares foi de que o município era uma circunscrição que precisava ser gerida dentro da mesma lógica assentada para o funcionamento do Estado, mas nunca concorrente dele. ${ }^{70}$

$\mathrm{Na}$ montagem do Estado nacional brasileiro, os patronos da institucionalização do novo país pautaram-se em regras científicas, racionais, civilizatórias. ${ }^{71}$ Tal processo quis dar uma nova tônica às instituições vigentes, confirmando certa hierarquização dentro dos parâmetros do Estado moderno e sob as regras do modelo liberal em voga. ${ }^{72}$ Nesse contexto, as Câmaras Municipais tornaram-se mais uma dentre outras tantas instituições, com poderes limitados, mas conectadas com outras instâncias de poderes e com uma ampla gama de obrigações referentes ao governo local.

A nova ordem constitucional implantada a partir da década de 1820, em certa medida inclusiva, porque também precisava de gente para compor o aparelho burocrático, se preocupou com a adesão das elites espalhadas no imenso território ao projeto elaborado a partir do centro do poder, e os grupos alocados nas câmaras municipais também figuraram nesse processo. ${ }^{73}$ As leis então criadas não tinham a intenção exclusiva de suprimir as potencialidades políticas das elites camarárias, eram também instrumentos de instrução e inserção delas às prerrogativas do Estado moderno em construção. Logo, as municipalidades não ficaram nulificadas nem alijadas no processo, pois naquele contexto houve uma ratificação de suas funções governativas, o que ampliou suas possibilidades de intervenção no cotidiano das cidades e vilas do Império, e, como "efeito colateral", o realce do seu papel na dinâmica institucional de então.

Às Câmaras competiria o governo de tais espaços. Os agentes e os papéis a serem assumidos nessa governança foram especificados, categorizados dentro do parâmetro da Polícia Administrativa. Nesses limites, os legisladores retiraram as prerrogativas judiciosas e limitaram o papel camarário à esfera da administração local, buscando esvaziarem-nas da autonomia que no passado "contribuía para tornar o poder mais difuso". No entender de Vantuil Pereira, essa era "outra lógica política em um processo que necessitava de 
centralização". ${ }^{74}$ Processo esse que caminhava contrário à concepção corporativa de Estado, ${ }^{75}$ pois estava fundado num pacto social dos indivíduos entre si e o monarca. A partir dele, prevaleceu um arcabouço constitucional anteparado pelas leis racionais e racionalizantes, a divisão dos poderes, a criação de novos lugares de representação e exercício do poder político, a burocratização e estandardização das instituições, e outras tantas transformações estabelecidas e estabelecedoras de novas relações sociais e de legitimação do novo governo monárquico-constitucional ${ }^{76}$. Nesse ínterim, os legisladores da nação buscaram circunscrever as instituições municipais, assim como as demais, e impedir que elas rivalizassem entre si ou contra a autoridade central, e esse movimento punha em evidência o "papel de um centro político na nova unidade". Segundo Andrea Slemiam, a regulamentação das instituições imperiais era premente, e o seu estabelecimento por meio das regras institucionalmente estatuídas poderia fornecer os vínculos de ligação das diversas partes do Império.

Portanto, o panorama das reformas liberais no Império, em certa medida, imprimiu um caráter de complementariedade entre as esferas de poder local e provincial, conformando um bloco que deveria ser harmônico e interligado ao governo geral. Assim, o arranjo políticoinstitucional impetrados nas Casas Legislativas definiu "os poderes e sua forma de controle nas várias localidades", e desenhou as instituições provinciais à luz de um Estado que se queria construir sob os ritos modernos ${ }^{77}$.

Não é possível afirmarmos que as municipalidades foram reduzidas a meras cumpridoras de ordens do governo provincial. O próprio Feijó concordará mais tarde que as autoridades provinciais não tinham condições de descer aos níveis mais baixos da administração, sendo, na maioria das vezes, obrigadas a recorrer às funções camarárias quando o assunto era a intervenção no cotidiano citadino, ${ }^{78}$ pois o governo econômico da cidade era uma atribuição exclusiva delas. E quando os governos provinciais requeriam das Câmaras algo que não era da alçada municipal, poderiam facilmente receber uma negativa como resposta. Portanto, é preciso relativizar a relação daquelas autoridades, entendendo que elas ora atuavam numa direção mais autoritária, ora buscavam a conciliação de interesses. ${ }^{79}$

As Câmaras Municipais foram organizadas "como instituições da administração pública", sendo capazes de manter algum controle sobre o gerenciamento das questões locais. ${ }^{80}$ Ainda que limitadas pelas leis, tiveram ratificadas suas funções de maneira clara e objetiva, sem eliminar seu caráter de interlocutoras das demandas locais aos interesses imperiais (vice-versa). ${ }^{81}$ Portanto, continuaram como espaço de interesse das elites locais, que poderiam, por meio delas, exercer o controle sobre das práticas regulatórias, as interdições 
nos espaços citadinos, o controle social, vantagens pecuniárias nos negócios das arrematações, dos arrendamentos, dos empregos remunerados, só para citar alguns exemplos, alianças políticas no mundo da paróquia e projeção para a política regional e até mesmo da Corte $^{82}$. Destarte, elas eram também parte integrante do mundo político do Brasil do oitocentos, e suas elites peças importante na configuração dele. Seria jogando com essa e nessa estrutura burocrático-institucional que as elites regionais/locais procurariam acalentar ora os seus interesses particulares, ora as prerrogativas do Estado liberal em formação.

Desta feita, é mais prudente dizer que as Câmaras Municipais foram componentes necessários à máquina governativa de então, sem, contudo, ficarem alijadas de outras questões políticas, e que as elites ali alocadas, ao exercerem o papel que lhes competia, poderiam servir de anteparo ao Estado nacional brasileiro. Levando-se em consideração que, entre o estipulado na legislação e as práticas cotidianas da administração local havia muitos desvios, que ora beneficiavam as facções locais, ora corroboravam com os interesses do poder central.

Por isso, a necessidade de se lançar um olhar mais detalhado sobre o desdobramento daquelas leis, buscando-se contextualizar a sua elaboração, mas também a sua aplicabilidade. Reduzir a escala de observação pode ser uma ferramenta essencial para se perceber como essa reconfiguração se desdobrou na prática, e deslindar a atuação dos grupos ali inseridos e a importância disso para a consolidação dos ritos do Império Liberal brasileiro nos mais longínquos rincões do infante país.

\section{Notas}

\footnotetext{
${ }^{1}$ Sobre o Campo da História, conferir: BARROS, José Dee Assunção. O Campo da História: especialidades e abordagens. $5^{\text {a }}$ ed. Petrópolis, RJ: Vozes, 2008.

${ }^{2}$ SOUZA, Williams Andrade. O bom governo da municipalidade: notas sobre a Câmara Municipal do Recife e sua organização para a administração da cidade (1829-1849). Revista História, ano 05, vol. 01, nº 01, 2014, pp. 201-221. Disponível em: http://www.revistahistoria.com.br; OLIVEIRA, Kelly Eleutério Machado. No laboratório da nação: poder camarário e vereança nos anos iniciais da formação do Estado Nacional Brasileiro em fins do primeiro Reinado e nas Regências, Mariana, 1828-1836. Dissertação (Mestrado) - Universidade Federal de Minas Gerais, Faculdade de Filosofia e Ciências Humanas, 2013. ANDRADE, Pablo de Oliveira. A "legítima representante": Câmaras Municipais, Oligarquias e a institucionalização do Império Liberal Brasileiro (Mariana, 1822-1836). Dissertação (Mestrado em História), Universidade Federal de Ouro Preto, Mariana, 2012.

${ }^{3}$ Entenda-se "governo econômico" como um tipo de governo que consistia em um grande número de práticas e ações emanadas da Câmara municipal visando ordenar, disciplinar as relações sociais desenroladas no espaço urbano cujo fim era garantir o bem comum da urbe. COLEÇÃO das Leis do Império do Brasil de 1824. Rio de Janeiro: Imprensa Nacional, 1886, p. 78;

${ }^{4}$ FAORO, Raimundo. Os donos do poder: formação do patronato político brasileiro. 12. ed. Rio de Janeiro: Globo: 1997, pp. $33,187$.

${ }^{5}$ NOGUEIRA, Octaciano. Constituições Brasileiras: 1824. Brasília: Senado federal e Ministério da Ciência e tecnologia, Centro de Estudos Estratégicos, 2001, p. 33.
} 

${ }^{6}$ Lei de $1^{\circ}$ de outubro de 1828. Dá nova forma às Câmaras Municipais, marca suas atribuições, e o processo para a sua
eleição, e dos Juízes de Paz. In: COLEÇÃO das Leis do Império do Brasil de 1828. Rio de Janeiro: Tipografia Nacional, 1878.

${ }^{7}$ FAORO, 1997, p. 177.

${ }^{8}$ Conferir: BERNARDES, Denis Antônio de Mendonça. O patriotismo Constitucional: Pernambuco, 1820-1822. São Paulo: Hucitec: Fapesp; Recife, PE: UFPE, 2006; SILVA, Ana Rosa Cloclet da. Inventando a Nação. Intelectuais Ilustrados e Estadistas Luso-brasileiros na crise do Antigo Regime Português (1750-1822). São Paulo: Hucitec: Fapesp, 2006; FLÁVIO, José Gomes Cabral. Conversas reservadas: "vozes públicas", conflitos políticos e rebelião em Pernambuco no tempo da Independência do Brasil. Rio de Janeiro: Arquivo Nacional, 2013.

${ }^{9}$ SLEMIAN, Andrea. Sob o império das leis: Constituição e unidade nacional na formação do Brasil (1822-1834). Tese (Doutorado em História) - Universidade de São Paulo, São Paulo 2006, p. 14.

${ }^{10}$ ANAIS da Câmara dos Deputados de 1826. Disponível em: <http://www.camara.gov.br〉. Acesso em: 11/01/2016. Sessão de 11 de maio de 1826, p. 41.

${ }^{11}$ SLEMIAN, 2006, pp. 182, 204.

${ }^{12}$ Conferir: SLEMIAN, 2006.

${ }^{13}$ ANAIS da Câmara dos Deputados. Sessão de 11 de julho de 1826, p. 127; SLEMIAN, 2006, pp. 144-148.

${ }^{14}$ ANAIS da Câmara dos Deputados. Sessão de 11 de julho de 1826, p. 128.

${ }_{15}^{15}$ ANAIS da Câmara dos Deputados. Sessão de 11 de julho de 1826, p. 127.

${ }^{16}$ ANAIS da Câmara dos Deputados. Sessão de 30 de agosto 1826, p. 312.

${ }^{17}$ ANAIS da Câmara dos Deputados de 1827. Disponível em: <http://www.camara.gov.br〉. Acesso em: 11/01/2016. Sessão de 17 de maio de 1827 , p. 117.

${ }^{18}$ Idem, p. 118. Grifos nossos.

${ }^{19} \mathrm{O}$ debate sobre este projeto foi iniciado pelos sanadores na $25^{\text {a }}$ sessão, em 01 de junho de 1827 , conforme veremos a diante.

${ }^{20}$ ANAIS da Câmara dos Deputados. Sessão de 18 de maio de 1827, p. 128.

${ }^{21}$ Segundo a autora, o esvaziamento dos poderes das municipalidades, travado na Câmara dos Deputados, era parte do processo de desmonte da persona Pedro I. SOUZA, Iara Lis Carvalho. Pátria Coroada: o Brasil como Corpo Político Autônomo - 1780-1831. São Paulo: Fundação Editora da UNESP, 1999, p. 340.

${ }^{22}$ PEREIRA, Vantuil. Ao Soberano Congresso: direitos do cidadão na formação do Estado imperial brasileiro (1822-1831). São Paulo: Alameda, 2010, pp. 254, 255.

${ }^{23}$ Nossa digressão retomará apenas os pontos debatidos que considerarmos mais significativos para o presente trabalho.

${ }^{24}$ ANAIS do Senado do Império. Segunda Sessão da Primeira Legislatura de 27 de abril a 14 de junho de 1827 . Tomo Primeiro. Rio de Janeiro, 1910. Disponível em: http://www.senado.leg.br/publicacoes/anais/asp/IP_AnaisImperio.asp. Acessado em: 15/08/2013. Sessão de 01 de junho de 1827, pp. 192, 193.

${ }^{25}$ ANAIS do Senado do Império. Sessão de 01 de junho de 1827, p. 193.

${ }^{26}$ Idem, p. 192.

${ }^{27}$ Idem.

${ }^{28}$ Idem, pp. 193, 194.

${ }^{29}$ ANAIS do Senado do Império. Sessões de 01 e 02 de junho de 1827, pp. 194-199.

${ }^{30}$ ANAIS do Senado do Império. Sessões de 01 e 02 de junho de 1827, p. 199.

31 Podiam votar e serem votados nas eleições para vereadores os que tivessem voto na nomeação dos eleitores de paróquia, ou seja, os que se enquadrassem nos artigos 91 e 92 da Constituição de 1824. Cf. NOGUEIRA, 2001, p. 91.

${ }^{32}$ Além de discutirem se a eleição para o cargo deveria ser pelo método direto ou indireto, se por maioria relativa ou absoluta dos votos, sinalizaram também que os lugares de vereadores eram relativamente disputados. Segundo o Marques de Caravelas, "em tão pequeno número de pessoas, [era] fácil haver suborno para que [votassem] ou [deixassem] de votar neste ou naquele, porque uns [ambicionariam] tais cargos por quererem representar, outros [procurariam] evita-los para se escusarem a incômodos." Os cargos municipais poderiam favorecer de alguma forma os grupos locais nas disputas facciosas em torno das posições de mando, por isso não deixavam de ser cobiçados por muitos políticos locais. Isso corrobora com o nosso entendimento sobre a importância político-administrativa das municipalidades naquele momento. ANAIS do Senado do Império. Sessões de 01 e 02 de junho de 1827, p. 195. Para um debate sobre participação política local no início do Oitocentos, conferir: MOTTA, Kátia Sausen da. Votantes ou eleitores? Os impasses na definição da participação política local no início do Oitocentos (1827-1828). In: OLIVEIRA, Camila Aparecida Braga [Et al]. Anais do XVIII Encontro Regional ANPUH-MG: Dimensões do poder na história. Mariana, MG, 2012. Disponível em: http://www.encontro2012.mg.anpuh.org/site/anaiscomplementares. Acessado em: 22/01/2016.

33 ANAIS do Senado do Império. Sessão de 06 de junho de 1827, pp. 204, 205.

${ }^{34}$ ANAIS do Senado do Império. Sessão de 06 de junho de 1827, p. 205.

${ }^{35}$ ANAIS do Senado do Império. Sessão de 08 de junho de 1827, p. 218.

${ }^{36}$ Idem, p. 219.

${ }^{37}$ ANAIS do Senado do Império. Sessão de 08 de junho de 1827, p. 219.

${ }^{38}$ Idem, p. 220.

${ }^{39}$ Idem.

${ }^{40}$ Idem, p. 221.

${ }^{41}$ Idem, pp. 221-222.

${ }^{42}$ Idem, p. 223. 
${ }^{43}$ Para um melhor entendimento sobre o conceito à época, conferir: URUGUAI, Visconde do. Visconde do Uruguai. Organização e introdução de José Murilo de Carvalho. São Paulo: Ed. 34, 2002. Especialmente as páginas 131- 191.

44 Segundo Paulino José Soares de Souza, "a lei de $1^{\circ}$ de outubro teve por fim separar o administrativo do judicial". URUGUAI, 2002, p. 170.

${ }^{45}$ ANAIS do Senado do Império. Sessão de 12 de junho de 1827, p. 242.

${ }^{46}$ Idem, p. 246.

${ }^{47}$ ANAIS do Senado do Império. Sessão de 15 de junho de 1827, p. 247.

ANAIS do Senado do Império. Sessão de 15 de junho de 1827, p. 248.

${ }^{49}$ Idem, p. 249.

${ }^{50}$ Esse debate apareceu novamente em 18 de julho, quando a Casa discutiu sobre o direito das Câmaras de criarem as posturas policiais e impor e executar penas por meio delas. Na ocasião, apesar das muitas interpelações, prevaleceu o mesmo consenso acima.

${ }^{51}$ ANAIS do Senado do Império. Segunda Sessão da Primeira Legislatura de 16 de julho a 12 de setembro de 1827. Tomo Segundo. Rio de Janeiro, 1911. Disponível em: http://www.senado.leg.br/publicacoes/anais/asp/IP_AnaisImperio.asp. Acessado em: 15/08/2013. Sessão de 18 de julho de 1827, p. 18.

52 Idem, p. 19.

${ }^{53}$ Idem, pp. 21-22.

${ }^{54}$ ANAIS do Senado do Império. Sessão de 19 de julho de 1827, p. 30.

55 A matéria rendeu idas e vindas junto à Comissão responsável. Na sessão de 29 de agosto os artigos aditivos sobre o tema entraram na pauta. Mas a discussão foi novamente suspensa e reencaminhada para que a Comissão revisse a questão dos vencimentos salariais para os respectivos cargos. ANAIS do Senado do Império. Sessão de 29 de agosto de 1827, pp. 266-9; Sessão de 10 de setembro de 1827, pp. 321.

${ }^{56}$ ANAIS do Senado do Império. Segunda Sessão da Primeira Legislatura de 13 de setembro a 16 de novembro de 1827. Tomo Terceiro. Rio de Janeiro, 1912. Disponível em: http://www.senado.leg.br/publicacoes/anais/asp/IP_AnaisImperio.asp. Acessado em: 15/08/2013. Sessões de 26, 27 e 28 de setembro e de 03 de outubro de 1827, pp. 67-68, 71-73, 81 e 108-109, respectivamente.

${ }^{57}$ ANAIS do Senado do Império. Sessão de 04 de outubro de 1827, p. 110-112.

${ }^{58}$ ANAIS do Senado do Império. Sessão de 05 de outubro de 1827, p. 116.

${ }^{59}$ Idem, p. 120.

${ }^{60}$ ANAIS do Senado do Império. Sessão de 22 de outubro de 1827, p. 210.

${ }^{61}$ ANAIS da Câmara dos Deputados. Sessão de 09 de maio de 1828, p. 30.

${ }^{62}$ ANAIS da Câmara dos Deputados de 1828. Disponível em: <http://www.camara.gov.br>. Acesso em: 11/01/2016. Sessão de 18 de junho de 1828 , p. 146.

${ }^{63}$ Idem, pp. 147-149.

${ }^{64}$ Sobre a discussão, conferir: MOTTA, 2012. Vide também a nota 32 neste trabalho.

${ }^{65}$ ANAIS da Câmara dos Deputados. Sessão de 20 de junho de 1828, pp. 159-160.

${ }^{66}$ Idem, pp.181-182.

${ }^{67}$ Anais da Câmara dos Deputados. Sessão de 26 de julho de 1828, p. 201.

${ }^{68}$ ANAIS do Senado. Sessão de 27 de agosto e 1828, p. 151.

${ }^{69}$ ANAIS da Câmara dos Deputados. Sessão de 23 de junho de 1828, p. 179.

${ }^{70}$ Para alguns do Senado, por exemplo, "o Conselho de Província trata[va] da administração geral dela, o que e[ra] mui distinto da parte municipal”. Mas outros não se persuadiam de que os deveres das Câmaras fossem de menores monta dos do Conselho. O consenso, porém, era de que a Constituição deu às Câmaras "o governo econômico e municipal das cidades e vilas, não o seu arbítrio, mas conforme a Lei” em discussão. Cumpria aos senadores dar forma a ela. ANAIS do Senado do Império. Sessão de 02 de junho de 1827, pp. 199, 200.

71 Uma leitura sobre o "absolutismo ilustrado" e suas permanências no contexto de formação do Estado brasileiro oitocentista, em: SOUZA, 2012, especialmente o capítulo I.

${ }^{72}$ Conferir: FRANCO, Maria Sylvia de Carvalho. Homens livres na ordem escravocrata. 2. ed. São Paulo: Ática, 1974; FLORY, Thomas. El juez de paz y el jurado en el Brasil imperial, 1808-1871. Control social y estabilidad politica en el nuevo Estado. México: Fundo de Cultura econômica, 1986; SILVA, Wlamir. Liberalismo e povo: a construção da hegemonia liberal-moderada na província de Minas Gerais (1830-1834. São Paulo: Aderaldo \& Rothschild; Belo Horizonte, MG: Fapeming, 2009; PEIXOTO, Antônio Carlos, [et al.]. O liberalismo no Brasil imperial: Origens, conceitos e prática. Rio de Janeiro, Revan: UERJ, 2013.

${ }^{73}$ MATTOS, Ilmar Rohloff de. O tempo saquarema. São Paulo: HUCITEC: Brasília, DF: INL, 1987.

${ }^{74}$ PEREIRA, 2010, p. 254.

${ }^{75}$ Sobre a questão, conferir: HESPANHA, António Manuel. O Antigo regime nos trópicos? Um debate sobre o modelo político do império colonial português. In: FRAGOSO, João; GOUVÊA, Maria de Fátima(Orgs.). Na trama das redes: Política e negócios no Império português, séculos XVI-XVIII. Rio de Janeiro: Civilização Brasileira, 2010, pp. 43-93; HESPANHA, António Manuel. A constituição do Império português. Revisão de alguns enviesamentos correntes. In: FRAGOSO, João; BICALHO, Maria Fernanda; GOUVÊA, Maria de Fátima (Orgs.). O Antigo Regime nos trópicos: a dinâmica imperial Portuguesa (Séculos XVI-XVIII). Rio de Janeiro: Civilização Brasileira, 2001, pp. 163-188. HESPANHA, António Manuel. Poder e instituições na Europa do Antigo Regime. Lisboa: Fundação Calouste Gulbenkian, 1984; HESPANHA, António Manuel. Caleidoscópio do Antigo Regime. São Paulo: Alameda, 2012; HESPANHA, António 
Manuel. Guiando a mão invisível: Direitos, Estado e Lei no liberalismo monárquico português. Coimbra: Livraria Almedina, 2004.

${ }^{76}$ Cf.: SOUZA, 2012; ANDRADE, 2012; OLIVEIRA, 2013; MARTINS, Maria Fernanda Vieira. A velha arte de governar: um estudo sobre elites a partir do Conselho de Estado (1842-1889). Rio de Janeiro, Arquivo Nacional, 2007; OLIVEIRA, Carlos Eduardo França de. Poder local e palavra impressa: a dinâmica política em torno dos Conselhos Provinciais e da imprensa periódica em São Paulo, 1824-1834. Dissertação (mestrado) - Universidade de São Paulo, São Paulo, 2009.

${ }^{77}$ SLEMIAN, 2006, pp. 140, 146, 175.

${ }^{78}$ FEIJÓ, Diogo Antônio. Guia das câmaras municipais do Brasil no desempenho de seus deveres por um deputado amigo da instituição. Rio de Janeiro, Typografia D’Astréa, 1830. Biblioteca Nacional. Obras raras. Para o deputado "cumpria também que as deliberações das Câmaras [Municipais] fossem acertadas e alinhadas pelas luzes que encampavam a administração do país naqueles idos do século XIX”. SOUZA, 2012, p. 73.

${ }^{79}$ ROSSATO, 2007, p. 113, 115, 143; Cf.: DOLHNIKOFF, 2005, p. 200-5; REIS, 1998, p. 665-76.

${ }^{80}$ ROSSATO, 2007, p. 51.

${ }^{81}$ GOUVÊA, Maria de Fátima Silva. O império das províncias: Rio de Janeiro, 1822-1889. Rio de Janeiro: Civilização Brasileira, 2008, p. 111.

${ }^{82}$ Conferir: VARGAS, Jonas Moreira. Entre a Paróquia e a Corte: os mediadores e as estratégias familiares da elite política do Rio Grande do Sul (1850-1889). Santa Maria: Ed. Da UFSM, 2010; Pelas margens do Atlântico: um estudo sobre elites locais e regionais no Brasil a partir das famílias proprietárias de charqueadas em Pelotas, Rio Grande do Sul (século XIX). Tese (Doutorado em História). Universidade Federal do Rio de Janeiro, Instituto de História, Programa de Pósgraduação em História Social, Rio de Janeiro, 2013.

\section{Referências bibliográficas}

ANDRADE, Pablo de Oliveira. A "legítima representante": Câmaras Municipais, Oligarquias e a institucionalização do Império Liberal Brasileiro (Mariana, 1822-1836). Dissertação (Mestrado em História), Universidade Federal de Ouro Preto, Mariana, 2012.

BARROS, José D’Assunção. O Campo da História: especialidades e abordagens. $5^{\mathrm{a}}$ ed. Petrópolis, RJ: Vozes, 2008.

BERNARDES, Denis Antônio de Mendonça. O patriotismo Constitucional: Pernambuco, 1820-1822. São Paulo: Hucitec: Fapesp; Recife, PE: UFPE, 2006.

FAORO, Raimundo. Os donos do poder: formação do patronato político brasileiro. 12. ed. Rio de Janeiro: Globo: 1997.

FLÁVIO, José Gomes Cabral. Conversas reservadas: "vozes públicas”, conflitos políticos e rebelião em Pernambuco no tempo da Independência do Brasil. Rio de Janeiro: Arquivo Nacional, 2013.

FLORY, Thomas. El juez de paz y el jurado en el Brasil imperial, 1808-1871. Control social y estabilidad politica en el nuevo Estado. México: Fundo de Cultura econômica, 1986.

FRANCO, Maria Sylvia de Carvalho. Homens livres na ordem escravocrata. 2. ed. São Paulo: Ática, 1974.

GOUVÊA, Maria de Fátima Silva. O império das províncias: Rio de Janeiro, 1822-1889. Rio de Janeiro: Civilização Brasileira, 2008.

HESPANHA, António Manuel. O Antigo regime nos trópicos? Um debate sobre o modelo político do império colonial português. In: FRAGOSO, João; GOUVÊA, Maria de Fátima(Orgs.). Na trama das redes: Política e negócios no Império português, séculos XVIXVIII. Rio de Janeiro: Civilização Brasileira, 2010. 
HESPANHA, António Manuel. A constituição do Império português. Revisão de alguns enviesamentos correntes. In: FRAGOSO, João; BICALHO, Maria Fernanda; GOUVÊA, Maria de Fátima (Orgs.). O Antigo Regime nos trópicos: a dinâmica imperial Portuguesa (Séculos XVI-XVIII). Rio de Janeiro: Civilização Brasileira, 2001, pp. 163-188.

HESPANHA, António Manuel. Poder e instituições na Europa do Antigo Regime. Lisboa: Fundação Calouste Gulbenkian, 1984.

HESPANHA, António Manuel. Caleidoscópio do Antigo Regime. São Paulo: Alameda, 2012; HESPANHA, António Manuel. Guiando a mão invisível: Direitos, Estado e Lei no liberalismo monárquico português. Coimbra: Livraria Almedina, 2004.

MARTINS, Maria Fernanda Vieira. A velha arte de governar: um estudo sobre elites a partir do Conselho de Estado (1842-1889). Rio de Janeiro, Arquivo Nacional, 2007.

MATTOS, Ilmar Rohloff de. O tempo saquarema. São Paulo: HUCITEC: Brasília, DF: INL, 1987.

MOTTA, Kátia Sausen da. Votantes ou eleitores? Os impasses na definição da participação política local no início do Oitocentos (1827-1828). In: OLIVEIRA, Camila Aparecida Braga [Et al]. Anais do XVIII Encontro Regional ANPUH-MG: Dimensões do poder na história. Mariana, $\quad 2012 . \quad$ Disponível em: http://www.encontro2012.mg.anpuh.org/site/anaiscomplementares. Acessado em: 22/01/2016.

NOGUEIRA, Octaciano. Constituições Brasileiras: 1824. Brasília: Senado federal e Ministério da Ciência e tecnologia, Centro de Estudos Estratégicos, 2001.

OLIVEIRA, Carlos Eduardo França de. Poder local e palavra impressa: a dinâmica política em torno dos Conselhos Provinciais e da imprensa periódica em São Paulo, 1824-1834. Dissertação (mestrado) - Universidade de São Paulo, São Paulo, 2009.

OLIVEIRA, Kelly Eleutério Machado. No laboratório da nação: poder camarário e vereança nos anos iniciais da formação do Estado Nacional Brasileiro em fins do primeiro Reinado e nas Regências, Mariana, 1828-1836. Dissertação (Mestrado) - Universidade Federal de Minas Gerais, Faculdade de Filosofia e Ciências Humanas, 2013.

PEIXOTO, Antônio Carlos, [et al.]. O liberalismo no Brasil imperial: Origens, conceitos e prática. Rio de Janeiro, Revan: UERJ, 2013.

SILVA, Ana Rosa Cloclet da. Inventando a Nação. Intelectuais Ilustrados e Estadistas Lusobrasileiros na crise do Antigo Regime Português (1750-1822). São Paulo: Hucitec: Fapesp, 2006.

SILVA, Wlamir. Liberalismo e povo: a construção da hegemonia liberal-moderada na província de Minas Gerais (1830-1834. São Paulo: Aderaldo \& Rothschild; Belo Horizonte, MG: Fapeming, 2009.

SLEMIAN, Andrea. Sob o império das leis: Constituição e unidade nacional na formação do Brasil (1822-1834). Tese (Doutorado em História) - Universidade de São Paulo, São Paulo 2006.

SOUZA, Iara Lis Carvalho. Pátria Coroada: o Brasil como Corpo Político Autônomo 1780-1831. São Paulo: Fundação Editora da UNESP, 1999. 
SOUZA, Williams Andrade. O bom governo da municipalidade: notas sobre a Câmara Municipal do Recife e sua organização para a administração da cidade (1829-1849). Revista História, ano 05, vol. 01, nº 01, 2014, pp. 201-221.

URUGUAI, Visconde do. Visconde do Uruguai. Organização e introdução de José Murilo de Carvalho. São Paulo: Ed. 34, 2002.

Vantuil. Ao Soberano Congresso: direitos do cidadão na formação do Estado imperial brasileiro (1822-1831). São Paulo: Alameda, 2010.

VARGAS, Jonas Moreira. Entre a Paróquia e a Corte: os mediadores e as estratégias familiares da elite política do Rio Grande do Sul (1850-1889). Santa Maria: Ed. Da UFSM, 2010;

. Pelas margens do Atlântico: um estudo sobre elites locais e regionais no Brasil a partir das famílias proprietárias de charqueadas em Pelotas, Rio Grande do Sul (século XIX). Tese (Doutorado em História). Universidade Federal do Rio de Janeiro, Instituto de História, Programa de Pós-graduação em História Social, Rio de Janeiro, 2013.

\section{Fontes}

ANAIS da Câmara dos Deputados de 1826, 1827 e 1828. Disponível em: <http://www.camara.gov.br>. Acesso em: 11/01/2016.

ANAIS do Senado do Império. Segunda Sessão da Primeira Legislatura de 27 de abril a 14 de junho de 1827. Tomo Primeiro. Rio de Janeiro, 1910. Disponível em: http://www.senado.leg.br/publicacoes/anais/asp/IP_AnaisImperio.asp. Acessado em: 15/08/2013. Sessão de 01 de junho de 1827.

ANAIS do Senado do Império. Segunda Sessão da Primeira Legislatura de 16 de julho a 12 de setembro de 1827. Tomo Segundo. Rio de Janeiro, 1911. Disponível em: http://www.senado.leg.br/publicacoes/anais/asp/IP_AnaisImperio.asp. Acessado em: 15/08/2013.

ANAIS do Senado do Império. Segunda Sessão da Primeira Legislatura de 13 de setembro a 16 de novembro de 1827. Tomo Terceiro. Rio de Janeiro, 1912. Disponível em: http://www.senado.leg.br/publicacoes/anais/asp/IP_AnaisImperio.asp. Acessado em: 15/08/2013.

COLEÇÃO das Leis do Império do Brasil de 1824. Rio de Janeiro: Imprensa Nacional, 1886.

COLEÇÃO das Leis do Império do Brasil de 1828. Rio de Janeiro: Tipografia Nacional, 1878.

DIÁRIO da Câmara dos Deputados a Assembleia geral Legislativa do Império do Brasil, 1826. Disponível em: https://books.google.com.br. Acessado em: 12/01/2016.

FEIJÓ, Diogo Antônio. Guia das câmaras municipais do Brasil no desempenho de seus deveres por um deputado amigo da instituição. Rio de Janeiro, Typografia D’Astréa, 1830. Biblioteca Nacional. Obras raras. 